\title{
Phosphorus Contents in the Profile of an Oxisol With Continuous Application of Liquid Swine Manure
}

\author{
Louise Stefanello Hemielevski ${ }^{1}$, Línia Dayane Lopes Machado ${ }^{1}$, June Faria Scherrer Menezes ${ }^{1}$, \\ Paulo Fernandes Boldrin ${ }^{1} \&$ Isabela Volpi Furtini ${ }^{2}$ \\ ${ }^{1}$ Rio Verde University, Campus Universitário, Rio Verde, GO, Brazil \\ ${ }^{2}$ Embrapa Agrossilvipastoril, Sinop, MT, Brazil \\ Correspondence: June Faria Scherrer Menezes, Universidade de Rio Verde, Campus Universitário, Fazenda \\ Fontes do Saber, Caixa Postal 104, Cep: 75901-000, Rio Verde, GO, Brazil. Tel: 55-(64)-3611-2261. E-mail: \\ june@unirv.edu.br
}

Received: January 29, 2020

Accepted: March 29, $2020 \quad$ Online Published: April 15, 2020

doi:10.5539/jas.v12n5p112

URL: https://doi.org/10.5539/jas.v12n5p112

\begin{abstract}
This study aimed to evaluate the dynamics of phosphorus in the soil by the determination of phosphorus contents in an Oxisol cultivated with soybean during the 2016/2017 crop season, after 17 years of successive applications of liquid swine manure (LSM). The experiment was conducted in the experimental area of the University of Rio Verde. The treatments were: T1-control; T2-25 $\mathrm{m}^{3} \mathrm{ha}^{-1}$ of LSM; T3-50 $\mathrm{m}^{3} \mathrm{ha}^{-1}$ of LSM; T4-75 $\mathrm{m}^{3} \mathrm{ha}^{-1}$ of LSM; T5-100 $\mathrm{m}^{3} \mathrm{ha}^{-1}$ of LSM and T6-fertilization with mineral fertilizer. The subplots refer to soil depths: 0-10; 10-20 and $20-40 \mathrm{~cm}$. The LSM was applied to the soil surface by spraying, before soybean sowing and the mineral fertilizer was applied to the furrow at the time of planting. After soybean harvesting, soil samples were collected at the studied depths for the determination of the contents of $\mathrm{P}$ in the soil. The contents of $\mathrm{P}$ in percolated water are within the concentration range considered adequate for human consumption. As for the contents of $\mathrm{P}$ in the soil, LSM applications on the soil surface increased the available soil P up to the depth of $20 \mathrm{~cm}$. The highest dose of LSM applied to the soil promoted an increment of P contents that are within the safety range of the critical environmental limit of phosphorus (LCA-P), corresponding to $37 \%$ of this limit.
\end{abstract}

Keywords: environmental contamination, critical limit, organic residues, water quality

\section{Introduction}

For the agricultural use of Brazilian Cerrado soils, which are naturally acidic and with low fertility (Novais \& Smyth, 1999), there is a need to use high doses of phosphorus (P) from phosphate fertilizers or organic sources, such as pig manure, which are abundant in intensive breeding regions. Phosphorus has a strong interaction with the soil, being strongly fixed in the colloids of the soil (Barrow, 1983), causing much of the P supplied in fertilization to be made unavailable in the soil solution due to the phenomenon of $\mathrm{P}$ fixation in reactions with the soil components. As a result of fixation, $\mathrm{P}$ becomes part of low solubility compounds, being less available for plant absorption. However, the saturation of the surface layer of the soil with this nutrient also favors its release to the solution and, consequently, its loss by surface runoff or leaching via vertical drainage of the soil (Sharpley, 2015; Gatiboni et al., 2015). Excess P contents increase the risk of losses to aquatic systems, an environment where its excess can cause eutrophication, compromising an entire watershed (Sharpley, 2015), which, consequently, can make water unsuitable for consumption.

In Rio Verde, state of Goias, Brazil, there are major production systems of the swine industry, generating large amounts of liquid swine manure (LSM). This residue contains nutrients, mainly nitrogen (N) and phosphorus (P), as well as organic matter (Choudhary, Bailey, \& Grant, 1996). The application of this waste to soils via organic fertilization allows the use of its nutrients by crops in total or partial substitution with mineral fertilizers (Scherer, Baldissera, \& Nesi, 2007; Lourenzi et al., 2014; Sousa et al., 2014).

An important feature of LSM is the low contents of dry matter, which makes transportation to distant areas difficult due to logistical and economic reasons. Thus, it tends to be applied to areas close to the place of origin of the waste (Basso, Ceretta, Durigon, Poletto, \& Girotto, 2005). 
The application of LSM follows specific legislations, which may originate from municipal laws, such as the county of Rio Verde-GO, which limits the application of LSM to $180 \mathrm{~m}^{3} \mathrm{ha}^{-1}$ (Menezes et al., 2017). This dosage allows the disposal of high concentrations of manure to the soil regardless of the requirement of the crop. Consequently, the nutrient concentrations in the soil increase, especially when the dose exceeds the demand of the crop. Moreover, the contents of these nutrients might be excessive at the application sites (Mahmood et al., 2017).

The N:P balance of LSM is different from the N:P requirement of the crops. Generally, LSM has an N:P ratio ranging from 2:1 to 6:1, while crops consume between 7:1 to 11:1 (Sadeghpour, Kellerings, Vermeylen, Godwin, \& Czymmek, 2016). Therefore, medium to long-term applications of LSM can lead to an imbalance in the relationships between these nutrients, which might be aggravated when losses due to $\mathrm{N}$ volatilization occur (Sharpley \& Halvorson, 1994; Sharpley, Daniel, Sims, \& Pote, 1996). Prolonged and over dose applications can result in changes in the soil nutrient contents due to these imbalances (Scherer et al., 2007; Penha et al., 2015).

Unlike $\mathrm{P}$, which is not lost by volatilization and, as a consequence, accumulates in the soil, much of the $\mathrm{N}$ from LSM applied to the soil is lost through volatilization within the first 24 hours after application (Rauber et al., 2017). In tropical soils, such as most of the Brazilian soils represented by Oxisols, $P$ tends to remain in the superficial layers due to the soil mineralogical characteristics, which presents high concentrations of $\mathrm{Fe}$ and $\mathrm{Al}$ oxides, causing P to remain adsorbed in the system (Novais \& Smyth, 1999). Thus, the nutrient has its content increased in the soil, especially in areas where the amount of P applied via LSM is higher than those exported by crops, resulting excessive P build up in the soil (Lewandowiski, Moncrief, \& Drewitz, 2006).

According to Emídio (2012), phosphates can be present in water due to natural origins, from the natural result of the decomposition of biological matter and mineral leaching, and also due to anthropogenic actions, as a result of erosion of fertilized agricultural land and failures in wastewater treatment. In natural waters, the phosphorus content should not exceed $1.0 \mathrm{mg} \mathrm{L}^{-1}$ of $\mathrm{P}_{2} \mathrm{O}_{5}$ (Alves, 2012).

In sloping areas, when there is excess $\mathrm{P}$, there is a potential loss of nutrient due to runoff, configuring the risk to water quality, resulting in eutrophication of water bodies (Gatiboni, Brunetto, Kaminski, \& Rheinheimer, 2008). In some European countries and in the United States where swine production is intense, the manure generated by this production system is the main cause of surface water eutrophication (Sharpley \& Halvorson, 1994). Thus, regulatory pressures must exist to prevent the application of phosphate mineral waste or fertilizers in areas where there is excess P in the soil, since they exist in some regions of the country, as reported by Gatiboni, Smyth, Scmitt, Cassol \& Oliveira (2015) for the state of Santa Catarina, in Brazil, and by Sharpley (2015) in the United States of America.

This study aimed to evaluate the potential risk of environmental contamination of $\mathrm{P}$ due to the successive use of liquid swine manure, using the critical environmental phosphorus (LCA-P) method and water percolation.

\section{Materials and Methods}

\subsection{Study Area}

The experiment was conducted in an experimental area belonging to the University of Rio Verde, located at the "Fontes do Saber" Farm, in the city of Rio Verde, state of Goias, Brazil. The soil of the area is classified as clayey dystroferric Red Latosol (Oxisol), with $610 \mathrm{~g} \mathrm{~kg}^{-1}$ of clay and $4 \%$ of slope. The experiment has been conducted for 17 years of successive waste applications in soybean and corn crops rotation system.

\subsection{Statistical Design}

The study was conducted using a randomized block design in split plots, consisting of six fertilizations applied in the main plot and three soil depths in the subplot, with three repetitions. The fertilization treatments applied on the surface were: T1: control (without fertilization); T2: $25 \mathrm{~m}^{3} \mathrm{ha}^{-1}$ of LSM; T3: $50 \mathrm{~m}^{3} \mathrm{ha}^{-1}$ of LSM; T4: $75 \mathrm{~m}^{3}$ $\mathrm{ha}^{-1}$ of LSM; T5: $100 \mathrm{~m}^{3} \mathrm{ha}^{-1}$ LSM and T6: recommended mineral fertilization dose, according to the soil and crop needs (Sousa \& Lobato, 2004). The subplots refer to different evaluated soil depths: $0-10 \mathrm{~cm} ; 10-20 \mathrm{~cm}$ and $20-40 \mathrm{~cm}$.

The LSM (Table 1) was applied to the soil surface by one-time spraying (T2 to T5) prior to soybean sowing in a monoculture system and the mineral fertilization (T6) was applied to the furrow at the time of planting, at a dose of $380 \mathrm{~kg} \mathrm{ha}^{-1}$ of NPK with a formulation of 04.20.18. 
Table 1. Average nutrient contents in LSM applied in the experimental area from 2000 to 2017. UniRV, Rio Verde, GO, Brazil

\begin{tabular}{|c|c|c|c|c|c|c|}
\hline Crop seasons & $\mathrm{N}$ total & $\mathrm{P}$ & $\mathrm{K}$ & $\mathrm{Ca}$ & $\mathrm{Mg}$ & S \\
\hline & \multicolumn{6}{|c|}{ 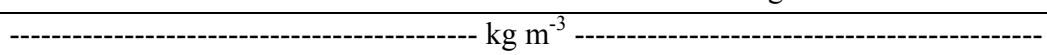 } \\
\hline 2000 to 2017 & 1.1 & 0.3 & 0.9 & 0.48 & 0.2 & 0.09 \\
\hline \multirow[t]{2}{*}{ Crop seasons } & $\mathrm{OM}$ & MS & Density & $\mathrm{pH}$ & $\mathrm{Cu}$ & $\mathrm{Zn}$ \\
\hline & \multicolumn{2}{|c|}{--------------- \% --------------- } & $\mathrm{kg} \mathrm{m}^{-3}$ & & \multicolumn{2}{|c|}{----------- $\mathrm{g} \mathrm{m}^{-3}$---------- } \\
\hline 2000 to 2017 & 1.0 & 1.24 & $1,006.5$ & 7.8 & 2.3 & 8.0 \\
\hline
\end{tabular}

The annual applied amounts of $\mathrm{P}$ as a function of the manure doses ranged from 21 to $83 \mathrm{~kg}^{-1}$ (Table 2), whereas for the mineral fertilization, an equivalent of $33.2 \mathrm{~kg} \mathrm{ha}^{-1}$ of $\mathrm{P}$ was applied.

Table 2. Contents of $P$ applied to the soil in the 2016/2017 crop season as a function of liquid swine manure (LSM) doses. UniRV, Rio Verde, GO, Brazil

\begin{tabular}{lllll}
\hline LSM doses $\left(\mathrm{m}^{3} \mathrm{ha}^{-1}\right)$ & 25 & 50 & 75 & 100 \\
\hline $\mathrm{P}\left(\mathrm{kg} \mathrm{ha}^{-1}\right)$ & 21 & 42 & 63 & 83 \\
\hline
\end{tabular}

Soybean sowing was carried out after the application of LSM on October 23, 2016, using a cultivar of high productive capacity (NS 6906 IPRO) with plant density of 16 plants $\mathrm{m}^{-1}$, in no-tillage system, with a spacing of $0.5 \mathrm{~m}$ between lines. Management and phytosanitary treatments were carried out according to the technical recommendations (Embrapa, 2010) and crop needs.

\subsection{Chemical Analysis}

After soybean harvest, soil samples were collected from the depths of 0-10, 10-20 and 20-40 cm, using Augers for soil sampling. A composite sample consisting of three simple samples was collected in each plot $(15 \mathrm{~m} \times 10$ $\mathrm{m}$ ) in order to determine the soil $\mathrm{P}$, sand, silt and clay contents. The determinations were performed in the Multiuse laboratories of the University of Rio Verde. The contents of $\mathrm{P}$ were determined by two methods: Mehlich-1 method $\left(0.05 \mathrm{~mol} \mathrm{~L}^{-1} \mathrm{HCl}+0.0125 \mathrm{~mol} \mathrm{~L}^{-1} \mathrm{H}_{2} \mathrm{SO}_{4}\right)$, as described by Mehlich (1953), and the $\mathrm{P}$ water method (P-water). The P-water contents were quantified after weighing the equivalent of $1 \mathrm{~cm}^{3}$ wet soil, adding $10 \mathrm{~mL}$ of distilled water, and stirring the samples for one hour in an end-over-end shaker at $30 \mathrm{rpm}$. The samples were then centrifuged at 5,000 rpm (approximately 2,000 g) for $10 \mathrm{~min}$, and the soil solution P was assessed following Murphy and Riley (1962). The contents of clay, silt, and sand were assessed using the pipette method (Embrapa, 1997).

The classification of the soil regarding the risks of $\mathrm{P}$ transferring to the soil solution was based on the $\mathrm{P}$ contents extracted by Mehlich-1 and the average soil clay content, following the methodology proposed by Gatiboni, Smyth, Scmitt, Cassol \& Oliveira (2015), in which P limit and P critical environmental limit (LCA-P) were evaluated. The LCA-P is a tool designed to estimate the relative risk of $\mathrm{P}$ loss from the soil. The proposed models to calculate P-Limit ( $y$, P-Mehlich 1 in $\mathrm{mg} \mathrm{dm}^{-3}$ and $x$, clay content in $\%$ ) and LCA-P (y, P-Mehlich 1 in $m g d m^{-3}$ and $x$, content of clay in $\%$ ) are obtained from Equations 1 and 2 . The average soil clay content in the 0 to $10 \mathrm{~cm}$ deep layer was $61 \%$.

$$
\begin{gathered}
y=54.3+1.18 x \\
y=40+x
\end{gathered}
$$

\subsection{Statistical Analysis}

All results were analyzed using analysis of variance (ANOVA). Significantly different means between treatments were separated with the Tukey's test at the 0.05 probability level. The Scheffé test was applied to compare mineral application versus LSM application and, when relevant, regression analysis was performed, using Sisvar 4.6 software (Build 6.1) (Ferreira, 2019).

\section{Results}

Table 3 shows the summary of the analysis of variance for the evaluated parameters: soil P content, water P content, limit P content, LCA-P and clay, silt and sand contents. 
Table 3. Summary of the analysis of variance of soil P, water P, limit P, LCA-P and clay, silt and sand contents. Rio Verde, GO, 2017

\begin{tabular}{|c|c|c|c|c|c|c|c|c|}
\hline \multirow{2}{*}{ VS } & \multirow{2}{*}{$\mathrm{DF}$} & \multicolumn{7}{|c|}{ Medium Square } \\
\hline & & P soil & P water & P limit & LCA-P & Clay & Silt & Sand \\
\hline Blocks & 2 & $3.406^{\mathrm{ns}}$ & $6.796^{\mathrm{ns}}$ & $11.749^{\text {ns }}$ & $13.019^{\text {ns }}$ & $13.019^{\mathrm{ns}}$ & $10.241^{\mathrm{ns}}$ & $0.056^{\mathrm{ns}}$ \\
\hline Fertilizing & 5 & $920.833^{* *}$ & $1055.841^{* *}$ & $13.454^{\mathrm{ns}}$ & $14.907^{\mathrm{ns}}$ & $14.907^{\mathrm{ns}}$ & $13.674^{\mathrm{ns}}$ & $3.944^{\mathrm{ns}}$ \\
\hline Mineral vs Doses & 1 & $182.537^{*}$ & $0.448^{\mathrm{ns}}$ & $34.098^{*}$ & $37.781^{*}$ & $37.781^{*}$ & $7.170^{\mathrm{ns}}$ & $5.633^{\mathrm{ns}}$ \\
\hline Doses & 4 & $1105.41^{* *}$ & $1319.689^{*}$ & $8.293^{\text {ns }}$ & $9.189^{\mathrm{ns}}$ & $9.189^{\mathrm{ns}}$ & $15.3^{\mathrm{ns}}$ & $3.522^{\mathrm{ns}}$ \\
\hline Error & 10 & 26.921 & 122.107 & 11.809 & 13.085 & 13.085 & 17.174 & 3.167 \\
\hline Depths & 2 & $390.871^{* *}$ & $1344.130^{* *}$ & $3.627^{\mathrm{ns}}$ & $4.019^{\mathrm{ns}}$ & $4.019^{\mathrm{ns}}$ & $9.463^{\text {ns }}$ & $11.167^{\text {ns }}$ \\
\hline Fertilizing vs Depths & 10 & $96.835^{* *}$ & $71.707^{\mathrm{ns}}$ & $7.899^{\mathrm{ns}}$ & $8.752^{\text {ns }}$ & $8.752^{\mathrm{ns}}$ & $11.73^{\mathrm{ns}}$ & $3.344^{\mathrm{ns}}$ \\
\hline (Mineral vs Doses) vs Depths & 2 & $26.162^{\mathrm{ns}}$ & $247.515^{\mathrm{ns}}$ & $12.638^{\mathrm{ns}}$ & $14.004^{\mathrm{ns}}$ & $14.004^{\mathrm{ns}}$ & $21.115^{\mathrm{ns}}$ & $1.94^{\mathrm{ns}}$ \\
\hline Doses vs Depths & 8 & $114.503^{* *}$ & $27.756^{\mathrm{ns}}$ & $6.714^{\mathrm{ns}}$ & $5.189^{\text {ns }}$ & $5.189^{\text {ns }}$ & $9.383^{\text {ns }}$ & $3.372^{\mathrm{ns}}$ \\
\hline Error & 24 & 12.499 & 91.583 & 3.953 & 4.380 & 4.380 & 5.574 & 4.4814 \\
\hline CV $(\%)$ & - & 42.01 & 44.67 & 1.96 & 2.07 & 3.42 & 17.66 & 8.34 \\
\hline
\end{tabular}

Note. $\mathrm{VS}=$ Variation Source; DF $=$ Degrees of Freedom; $\mathrm{CV}=$ Coefficient of Variation. $* *, *$ significant at $1 \%$ and $5 \%$ probability, respectively by $\mathrm{F}$ test. $\mathrm{ns}=$ not significant.

For the variable P-water, there was no interaction between fertilization and depths. When the effect of doses was evaluated, the quadratic regression model presented the best fit (Figure 1) regardless of soil depth. The maximum point for $\mathrm{P}$ content in water was $0.034 \mathrm{mg} \mathrm{L}^{-1}$ obtained at the dose of $19.84 \mathrm{~m}^{3} \mathrm{ha}^{-1}$, and from that dose there was a decrease of $\mathrm{P}$ content in water. Moreover, there were depth effects in relation to fertilization (Figure 2). The P-water contents were $0.015,0.017$ and $0.031 \mathrm{mg} \mathrm{L}^{-1}$ at the depths of $0-10 \mathrm{~cm}, 10-20 \mathrm{~cm}$ and $20-40 \mathrm{~cm}$, respectively.

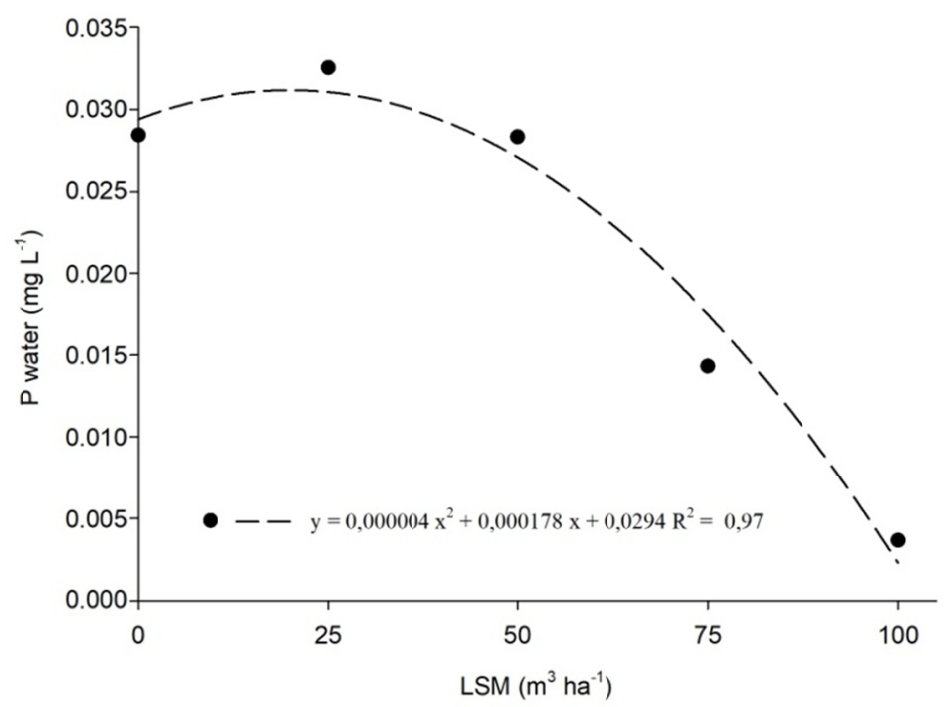

Figure 1. Contents of $\mathrm{P}$ in water as a function of liquid swine manure doses after application for 17 consecutive years of liquid swine manure (LSM), mineral fertilization and control in a dystroferric Red Latosol (Oxisol). Rio Verde, GO, 2017 


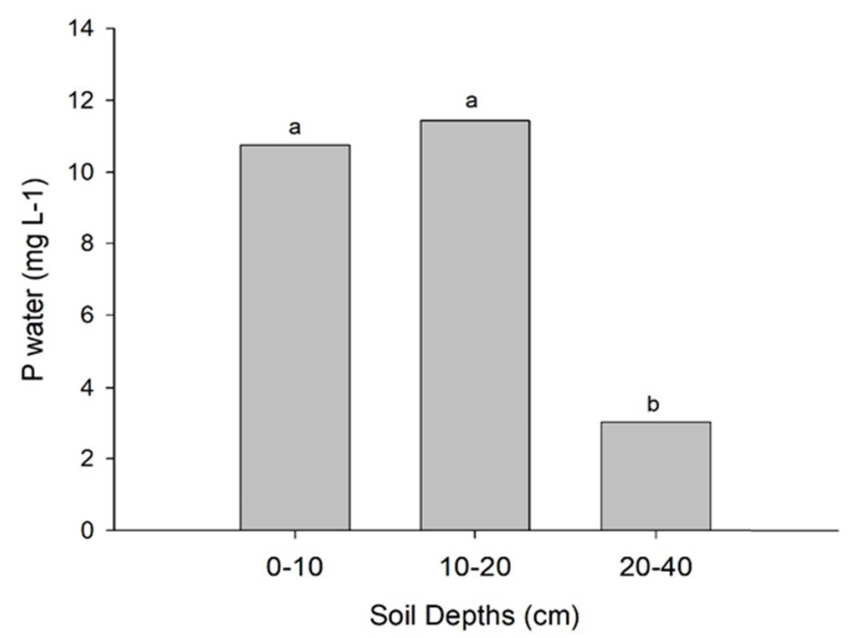

Figure 2. Average $\mathrm{P}$ water $\left(\mathrm{mg} \mathrm{L}^{-1}\right)$ in the 2016/2017 crop season as a function of soil depths of 0-10, 10-20 and 20-40 cm. UniRV, Rio Verde, GO, Brazil

As for the contents of $\mathrm{P}$ in the soil, there was an interaction effect between fertilization and soil depths. When analyzing the soil P content as a function of the applied LSM doses at each depth, a quadratic regression adjustment was observed for the depths $0-10 \mathrm{~cm}$ and $10-20 \mathrm{~cm}$. At the depth of 20-40, there was no significant effect (Figure 3). At a depth of 0-10 and 10-20 cm, the soil P contents showed minimum points of 30.4 and 27.8 $\mathrm{m}^{3} \mathrm{ha}^{-1}$, respectively. At higher doses, there was an increase in the soil P contents. Suitable soil P levels for clay contents ranging from 45 to $60 \%$ and higher than $60 \%$ are 8 to $12 \mathrm{mg} \mathrm{dm}^{-3}$ and 4.1 to $6.0 \mathrm{mg} \mathrm{dm}^{-3}$, respectively (Sousa \& Lobato, 2004).

The application of LSM on the soil surface under the no-tillage system provided higher amounts of $\mathrm{P}$ than those exported by crops, especially at the $100 \mathrm{~m}^{3} \mathrm{ha}^{-1}$ dose of LSM, increasing the available soil P levels to up to the depths of $20 \mathrm{~cm}$. Therefore, there was no model adjustment for the depth of $20-40 \mathrm{~cm}$.

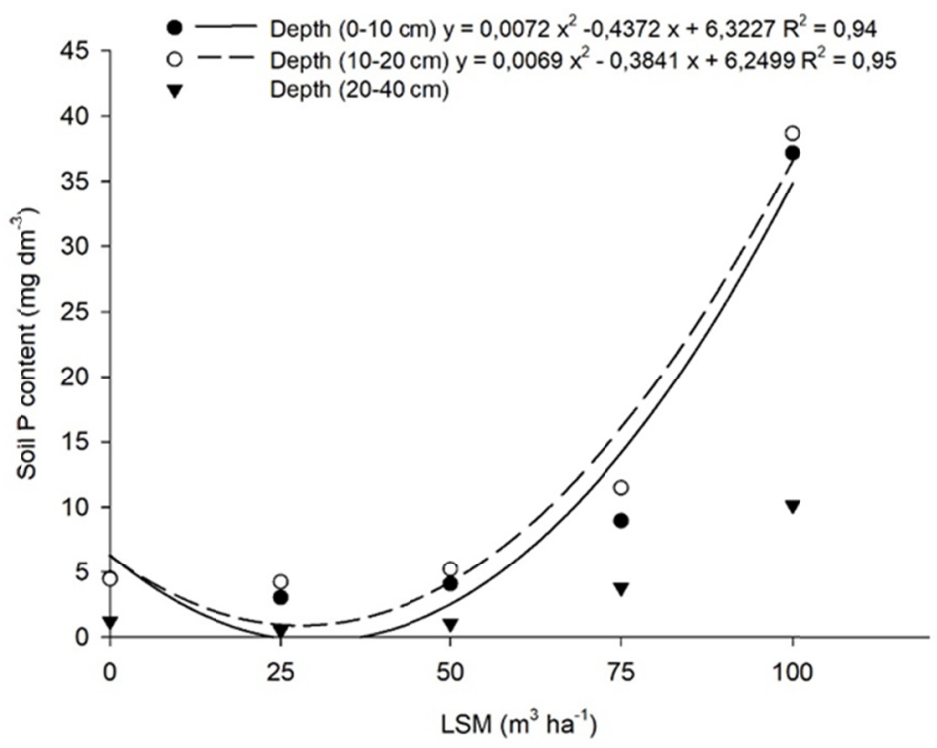

Figure 3. Soil P contents as a function of LSM doses and different soil depths after application of 18 consecutive years of LSM, mineral fertilization and control in a dystroferric Red Latosol. Rio Verde, GO, Brazil, 2017

Regarding the contents of soil P, P Limit and LCA-P, a contrast test was performed to compare the effect of mineral application versus LSM application (Table 4). The application of LSM provided higher soil P contents than the mineral fertilization, whereas for P Limit and LCA-P there were no differences. 
It should be noted that mineral fertilization is based on crop needs and added nutrients, when soluble, are readily available to the plant, while LSM applications must go through the mineralization process to make them available. This factor might have influenced the higher availability of P in the soil with LSM application, since the $\mathrm{P}$ mineralization is only 60\% (Ribeiro, Guimaraes, \& Alvarez, 1999) in the current application, but the previous applications of LSM increase the P mineralization because of that residual effect.

Table 4. Contrasts of mean $\mathrm{P}$ in soil and $\mathrm{P}$ Limit under fertilization with doses of liquid swine manure $(0 ; 25 ; 50$; $75 ; 100 \mathrm{~m}^{3} \mathrm{ha}^{-1}$ ) in relation to mineral fertilization (N-P-K)

\begin{tabular}{llll}
\hline Treatments & P soil & P Limit & LCA-P \\
\hline & $--1 .-10$ & 101.87 & 101.44 \\
Mineral & 4.30 & $101.22^{\mathrm{ns}}$ & $100.76^{\mathrm{ns}}$ \\
\hline
\end{tabular}

Note. * Significant by the F test.

Most of the mineral $\mathrm{P}$ applied to the soil was not available in the labile fraction in the soil when using the Mehlich-1 extractor. Less than 50\% of the total applied $\mathrm{P}$ was recovered from the labile fraction to a depth of 40 $\mathrm{cm}$. For doses of LSM up to $75 \mathrm{~m}^{3} \mathrm{ha}^{-1}$, most of the available P was found below $10 \mathrm{~cm} \mathrm{depth}$. When $100 \mathrm{~m}^{3}$ ha of LSM was applied, the effect of P accumulation over the 17 years of application was higher than $100 \%$ up to the depth of $20 \mathrm{~cm}$ (superficial layer) (Figure 4).

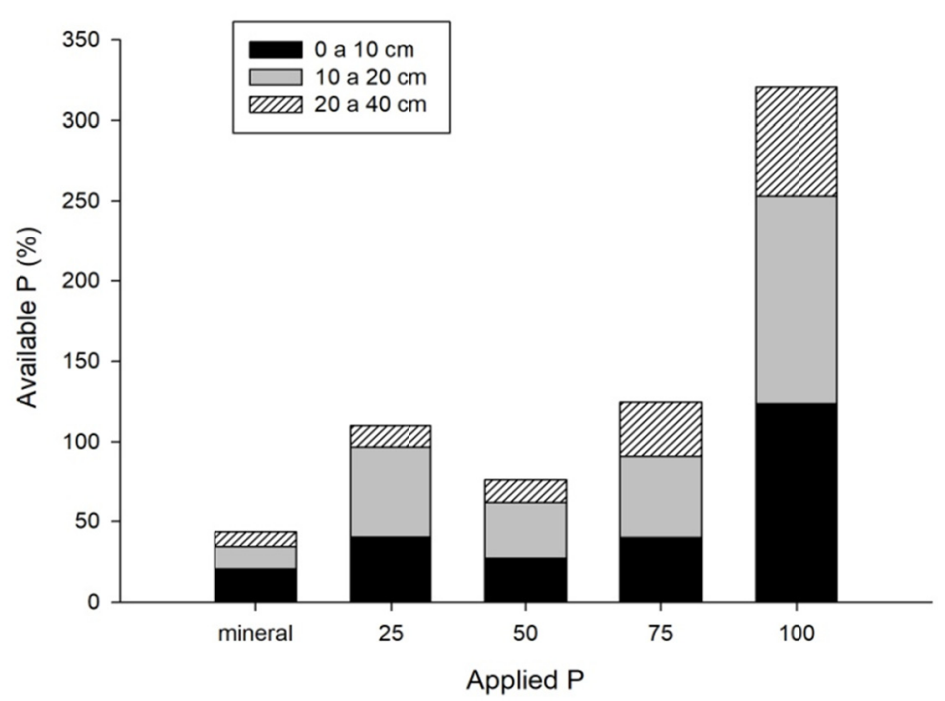

Figure 4. Percentage of available soil P (extracted by Mehlich-1) at the depths of 0-10, 10-20 and 20-40 cm as a function of $\mathrm{P}$ applied with different fertilizers (mineral, 25, 59, 65 and $100 \mathrm{~m}^{3} \mathrm{ha}^{-1}$ of LSM) corresponding to $33.2,7.5,15,22.5$ and $30 \mathrm{~kg} \mathrm{ha}^{-1}$, respectively

\section{Discussion}

With the long-term application of LSM, there was an increase of $\mathrm{P}$ in the soil higher than $30 \mathrm{mg} \mathrm{dm}^{-3}$ in the highest applied doses, which is considered high for soils with $61 \%$ of clay texture. This represents an increase of approximately $400 \%$. High levels of soil $\mathrm{P}$ are often caused by a history of excessive manure application (Lewandowski, Moncrief, \& Drewitz, 2006). The results indicate that P is accumulating in the soil, more on the surface, but the transfer to water by leaching is in minimal quantities, but not higher enough to cause potential problems (Figure 1). Although there is P build-up in the soil, it does not reach the problematic level at least in the first 17 years of application. Future research is needed to assess the impacts of manure application on soil in more chemical properties that can affect crop production and the environment.

When $100 \mathrm{~m}^{3} \mathrm{ha}^{-1}$ of LSM was applied, the effect of $\mathrm{P}$ accumulation over the 17 years of application was greater than $100 \%$ up to the depth of $20 \mathrm{~cm}$ (superficial layer) (Figure 4). This result indicates that the amount applied at 
this dose exceeds soybean P extraction by approximately $5.5 \mathrm{~g} \mathrm{P} \mathrm{kg}^{-1}$ of harvested grain (Cunha, Casarin, \& Prochnow, 2010). Thus, when manure is over applied during the soybean season, there is an excess of $\mathrm{P}$ when comparing with the crop P requirement. Ceretta et al. (2010) using $80 \mathrm{~m}^{3} \mathrm{ha}^{-1}$ of LSM broadcasted in the soil for seven years, also found that LSM increase P contents in the soil mainly in labile fractions.

Boitt et al. (2018), in a study of pig-slurry addition for fifteen years, found $\mathrm{P}$ accumulation and vertical movement down the soil profile, mainly to the $0-20 \mathrm{~cm}$ soil depth, in proportion to application rates when applying 100 and $200 \mathrm{~m}^{3} \mathrm{ha}^{-1} \mathrm{y}^{-1}$. These results are due to the application of manure that was performed superficially without incorporation and with the permanence of crop residues on the soil surface (Adeli, Bolster, Rowe, McLaughlin, \& Brink, 2008; Mellek et al., 2010; Lou, Xu, Wang, Sun, \& Liang, 2011; Lourenzi et al., 2011). The research carried out by Antonelli et al. (2019) shows the opinion of many other scientists who consider the application of LSM a non-sustainable soil management practice due to its negative effects leading to water pollution. Tabbara (2003) confirmed the potential loss of P only 24 hours after applying the manure, interpreted as a risk of transportation to the land surface through surface runoff and erosion, especially in slopes areas.

In unpolluted natural waters, $\mathrm{P}$ concentrations range from $0.010 \mathrm{mg} \mathrm{L}^{-1}$ to $0.050 \mathrm{mg} \mathrm{L}^{-1}$ (Ministry of Health, 2006). Therefore, the values determined in the present study at different depths are lower than the reference value $\left(1.0 \mathrm{mg} \mathrm{L}^{-1}\right)$ for natural waters. In addition, these values are within the range of $\mathrm{P}$ levels in drinking water $\left(<0.050 \mathrm{mg} \mathrm{L}^{-1}\right)$. If long-term LSM inputs can increase quantities of $\mathrm{P}$ in soil, there is a potential to enhance the $\mathrm{P}$-water, so critical levels of $\mathrm{P}$ in soils must be carefully monitored avoid $\mathrm{P}$ transfer to groundwater in the future or some soil conservationist practices should be adopted, as described by Labrière et al. (2015).

For safety reasons, it is recommended that the application of LSM or phosphate fertilizer should not be allowed after the suitable soil P level of soil, 8 to $12 \mathrm{mg} \mathrm{dm}^{-3}$ (Sousa \& Lobato, 2004) is reached because this indicates high risk of soil becoming a source of $\mathrm{P}$ pollution to surface waters. After 17 years of successive applications of LSM in the same place, the dose of $100 \mathrm{~m}^{3} \mathrm{ha}^{-1}$ was considered excessive, because it increases the P contents in the soil even in deeper soil layers, indicating that it would be an unsustainable dose in areas where the application of swine manure is required.

The soil P-limit was $101 \mathrm{mg} \mathrm{dm}^{-3}$ (Table 4) from P-Mehlich-1 for soil with $61 \%$ clay, following the methodology proposed by Gatiboni, Smyth, Scmitt, Cassol, and Oliveira (2015). Further studies are being carried out in order to define a more accurate P-limit equation for specific soils of the Brazilian Cerrado, such as Oxisols. Sharpley, Mcdowell, Weld, and Kleinmann (2001) chased $75 \%$ of P-limit values to be maximum value in soils from the State of Pennsylvania-USA, beyond which measures restricting supplementation with P should be adopted.

\section{Conclusions}

Successive application of LSM and mineral fertilization does not influence the transfer of $\mathrm{P}$ to water after 17 years of successive applications. The contents of $P$ in water at the depths of $0-10 \mathrm{~cm}, 10-20$ and $20-40 \mathrm{~cm}$ are within the concentration range considered suitable for human consumption and was not aggressive to the environment.

As for the soil P content, soil surface LSM applications increased the available levels of soil P to a depth of up to $20 \mathrm{~cm}$, especially with the highest dose of LSM.

The highest dose of LSM applied to the soil increased the P content in the soil within the safe range of the LCA-P, corresponding to $37 \%$ of this limit.

\section{Acknowledgements}

This research was part of the project Monitoring the environmental impact caused by the use of liquid swine manure in agriculture. The authors are grateful to the Fundação de Amparo à Pesquisa do Estado de Goiás (FAPEG), Conselho Nacional de Desenvolvimento Científico e Tecnológico (CNPq), Empresa Brasileira de Pesquisa Agropecuária (EMBRAPA), BRF-Brasil Foods and Universidade de Rio Verde (UniRV), all from Brazil, for financial support and scholarships.

\section{References}

Adeli, A., Bolster, C. H., Rowe, D. E., McLaughlin, M. R., \& Brink, G. E. (2008). Effect of long-term swine effluent application on selected soil properties. Soil Science, 173, 223-235. https://doi.org/10.1097/ ss.0b013e31816408ae

Alves, C. (2012). Tratamento de águas de abastecimento (3rd ed., p. 382) Publindústria. 
Antoneli, V., Mosele, A. C., Bednarz, J. A., Pulido-Fernández, M., Lozano-Parra, J., Keesstra, S. D., \& Rodrigo-Comino, J. (2019). Efects of applying liquid swine manure on soil quality and yield production in tropical soybean crops (Paraná, Brazil). Sustainability, 11(14), 3898. https://doi.org/10.3390/su11143898

Barrow, N. J. (1983) A mechanistic model for describing the sorption and desorption of phosphate by soil. J. Soil Sci., 34, 733-750. https://doi.org/10.1111/ejss.12197

Basso, C. J., Ceretta, C. A., Durigon, R., Poletto, N., \& Girotto, E. (2005). Dejeto líquido de suínos. II-Perdas de nitrogênio e fósforo por percolação no solo sob plantio direto. Ciência Rural, 35, 1305-1312. https://doi.org/10.1590/S0103-84782005000600012

Boitt, G., Schmitt, D. E., Gatiboni, L. C., Wakelin, S. A., Black, S. W., Cassol, P. C., ... Condron, L. M. (2018). Fate of phosphorus applied to soil in pig slurry under cropping in southern Brazil. Geoderma, 321, 164-172. https://doi.org/10.1016/j.geoderma.2018.02.010

Ceretta, A., Felipe Lorensini, F., Brunetto, G., Girotto, E., Gatiboni, L. C, Lourenzi, C. R., ... Miotto, A. (2010). Frações de fósforo no solo após sucessivas aplicações de dejetos de suínos em plantio direto. Pesq. Agropec. Bras., 45(6), 593-602. https://doi.org/10.1590/S0100-204X2010000600009

Choudhary, M., Bailey, L. D., \& Grant, C. A. (1996). Review of the use of swine manure in crop production effects on yield and composition and on soil and water quality. Waste Management \& Research, 14, 581-595. https://doi.org/10.1177/0734242X9601400606

Cunha, J. F., Casarin, V., \& Prochnow, L. I. (2010). Balanço de nutrientes na agricultura brasileira. Informações Agronômicas, 130, 1-11.

EMBRAPA (Empresa Brasileira de Pesquisa Agropecuária). (1997). Embrapa Centro Nacional de Pesquisa do Solo. Manual de métodos de análise de solo (2nd ed.). Rio de Janeiro, Brazil.

EMBRAPA (Empresa Brasileira de Pesquisa Agropecuária). (2010). Embrapa Soja. Tecnologias de produção de soja: Região Central do Brasil, 2011 (p. 247). Londrina, Brazil.

Emídio, V. J. G. (2012). A problemática do fósforo nas águas para consumo humano e águas residuais e soluções para o seu tratamento (p. 118, Dissertação de mestrado da Faculdade de Algarve, Portugal). Retrieved from http://hdl.handle.net/10400.1/3154

Ferreira, D. F. (2019). Sisvar: A computer analysis system to fixed effects split plot type designs. Revista Brasileira de Biometria, 37(4), 529-535. https://doi.org/10.28951/rbb.v37i4.450

Gatiboni, L. C., Brunetto, G., Kaminski, J., \& Rheinheimer, D. dos S. (2008). Fósforo da biomassa microbiana e atividade de fosfatases ácidas durante a diminuição do fósforo disponível no solo. Pesquisa Agropecuaria Brasileira, 43(8), 1085-1091. https://doi.org/10.1590/S0100-204X2008000800019

Gatiboni, L. C., Smyth, T. J., Scmitt, D. E., Cassol, P. C., \& Oliveira, C. M. B. de. (2015). Soil phosphorus thresholds in evaluating risk of environmental transfer to surface water in Santa Catarina, Brazil. Revista Brasileira de Ciências do Solo, 39(4), 1225-1234. https://doi.org/10.1590/01000683rbcs20140461

Labrière, N., Locatelli, B., Laumonier, Y., Freycon, V., \& Bernoux, M. (2015). Soil erosion in the humid tropics: A systematic quantitative review. Agric. Ecosyst. Environ., 203, 127-139. https://doi.org/10.1016/j.agee. 2015.01.027

Lewandowski, A., Moncrief, J., \& Drewitz, M. (2006). The Minnesota Phosphorus Index: Assessing Risk of Phosphorus Loss from Cropland. University of Minnesota Extension Service AG-BU-08423. Retrieved from http: //www.mnpi.umn.edu

Lou, Y., Xu, M., Wang, W., Sun, X., \& Liang, C. (2011). Soil organic carbon fractions and management index after 20 years of manure and fertilizer application for greenhouse Vegetables. Soil Use and Management, 27(2), 163-169. https://doi.org/10.1111/j.1475-2743.2010.00325.x

Lourenzi, C. R., Ceretta, C. A., Brunetto, G., Girotto, E., Tiecher, T. L., Vieira, R. C. B., ... Ferreira, P. A. A. (2014). Pig slurry and nutrient accumulation and dry matter and grain yield in various crops. Revista Brasileira de Ciência do Solo, 38(3), 949-958. https://doi.org/10.1590/S0100-06832014000300027

Lourenzi, C. R., Ceretta, C. A., Silva, L. S. da, Trenti, G., Girotto, E., Lorensini, F., ... Brunetto, G. (2011). Soil chemical properties related to acidity under successive pig slurry application. Revista Brasileira de Ciência do Solo, 35(5), 1827-1836. https://doi.org/10.1590/S0100-06832011000500037 
Mahmood, F., Khan, I., Shahzaf, T., Ashraf, U., Hussain, S., Shahid, M., ... Ullah, S. (2017). Effects of organic and inorganic manures on maize and their residual impact on soli physico-chemical properties. Journal of Soil and Plant Nutrition, 17(1), 22-32. https://doi.org/10.4067/S0718-95162017005000002

Mehlich, A. (1953). Determination of $\mathrm{P}, \mathrm{Ca}, \mathrm{Mg}, \mathrm{K}, \mathrm{Na}$ and $\mathrm{NH}_{4}$ by North Carolina Soil Testing Laboratories. Raleigh, University of North Carolina.

Mellek, J. E., Dieckow, J., Silva, V. L. D., Pauletti, V., Vezzani, F. M., ... Souza, J. L. M. (2010). Dairy liquid manure and no-tillage: Physical and hydraulic properties and carbon stocks in a Cambisol of Southern Brazil. Soil \& Tillage Research, 110(1), 69-76. https://doi.org/10.1016/j.still.2010.06.005

Menezes, J. F. S., Teodoro, A. O. A., Berti, M. P. S., Menezes, C. C. E., Cantão, V. C. G., Caetano, J. O. C., ... Benites, V. M. (2017). Long-term application of liquid swine manure can increase $\mathrm{Cu}$ and $\mathrm{Zn}$ contents in the pasture soils. Australian Journal of Crop Science, 11(6), 744-748. https://doi.org/10.21475/ajcs.17. 11.06.p528

Ministry of Health (Ministério da Saúde/Secretaria de Vigilância em Saúde). (2006). Manual of Procedures on Environmental Health Surveillance Related to the Water Quality for Human Consumption (Série B, Textos Básicos de Saúde, p. 212). Brasília: Ministério da Saúde. Retrieved from http://www.saude.gov.br/bvs

Murphy, J., \& Riley, J. P. (1962). A modified single solution method for the determination of phosphate in natural waters. Anal Chim Acta, 27, 31-6. https://doi.org/10.1016/S0003-2670(00)88444-5

Novais, R., \& Smyth, T. J. (1999). Fósforo em solo e planta em condições tropicais (p. 399). Viçosa, MG: UFV, DPS.

Penha, H. G. V., Menezes, J. F. S., Silva, C. A., Lopes, G., Carvalho, C. de A., Ramos, S. J., ... Guilherme, L. R. G. (2015). Nutrient accumulation and availability and crop yields following long-term application of pig slurry in a Brazilian Cerrado soil. Nutrient Cycling in Agroecosystems, 101(2), 259-269. https://doi.org/ 10.1007/s10705-015-9677-6

Rauber, L. P., Andrade, A. P., Borges Jr., W. S., Mafra, A. L., Andreola, A., \& Gatiboni, L. C. (2017). Ammonia volatilization with swine slurry injection and use of nitrification. Revista Ceres, 46(3), 307-314. https://doi.org/10.1590/0034-737x201764030012

Ribeiro, A. C., Guimarães, P. T. G., \& Alvarez, V., V. H. (1999). Recomendação para uso de recorretivos de corretivos e fertilizantes para o estado de Minas Gerais ( $5^{\text {a }}$ aproximação, p. 359). Viçosa, CFSEMG.

Sadeghpour, A., Kellerings, Q. M., Vermeylen, F., Godwin, G. S., \& Czymmek, K. J. (2016). Nitrogen-vs Phosphorus-based manure and compost management of corn. Agronomy Journal, 108(1), 185-195. https://doi.org/10.2134/agronj2015.0218

Scherer, E. E., Baldissera, I. T., \& Nesi, C. N. (2007). Propriedades químicas de um Latossolo vermelho sob plantio direto e adubação com esterco de suínos. Revista Brasileira de Ciência do Solo, 31(1), $123-131$. https://doi.org/10.1590/S0100-06832007000100013

Sharpley, A. (2015). Managing agricultural phosphorus to minimize water quality impacts. Sci. Agric., 73(1), 1-8. https://doi.org/10.1590/0103-9016-2015-0107

Sharpley, A. N., \& Halvorson, D. A. (1994). The management of soil phosphorus availability and its impact on surface water quality. In R. Lal \& B. A. Stewart (Eds.), Soil Processes and Water Quality (pp. 87-89). Madison, USA.

Sharpley, A. N., Mcdowell, R. W., Weld, J. L., \& Kleinmann, J. A. (2001). Assessing site vulnerability to phosphorus loss in an agricultural watershed. Journal Environmental Quality, 30(6), $2026-36$. https://doi.org/10.2134/jeq 2001.2016

Sharpley, A., Daniel, T. C., Sims, J. T., \& Pote, D. H. (1996). Determining environmentally sound soil phosphorus levels. Journal Soil Water Conservation, 51(2), 160-166. Retrieved from https://www.jswconline.org/content/51/2/160

Sousa, D. M. G. de, \& Lobato, E. (2004). Cerrado: Correção do solo e adubação (2nd ed., p. 416) Brasília, DF: Embrapa Cerrados.

Sousa, F. A., Silva, E. B., Campos, A. T., Gandini, A. M. M., Corrêa, J. M., ... Grazziotti, P. H. (2014). Atividade microbiana e produção da lavoura cafeeira após adubação com dejetos líquidos de suínos. Bioscience Journal, 30(4), 1041-1049. https://doi.org/10.32404/rean.v5i1.1747 
Tabbara, H. (2003). Phosphorus loss to runoff water twenty-four hours after application of liquid swine manure or fertilizer. J. Environ. Qual., 32, 1044-1052. https://doi.org/10.2134/jeq2003.1044

\section{Copyrights}

Copyright for this article is retained by the author(s), with first publication rights granted to the journal.

This is an open-access article distributed under the terms and conditions of the Creative Commons Attribution license (http://creativecommons.org/licenses/by/4.0/). 